\title{
Blue gourami (Trichogaster trichopterus) gonadotropic $\beta$ subunits (I and II) cDNA sequences and expression during oogenesis
}

\section{K Jackson ${ }^{1,3}$, D Goldberg' ${ }^{1}$, M Ofir ${ }^{1}$, M Abraham and G Degani ${ }^{1,2}$}

${ }^{1}$ MIGAL, Galilee Technological Center, Kiryat Shmona 10200, Israel

${ }^{2}$ Golan Research Institute, University of Haifa, Israel

${ }^{3}$ Hebrew University, Jerusalem, Israel

(Requests for offprints should be addressed to G Degani, MIGAL, Galilee Technological Center, Kiryat Shmona 10200, Israel)

\begin{abstract}
We have cloned two cDNAs from the pituitary gland of blue gourami (Trichogaster trichopterus), coding for the $\beta$ subunits of the gonadotropin hormones GtH-I and GtH-II. The two cDNAs were sequenced and subjected to sequence analysis. We have found that the deduced amino acid sequences of both cDNAs were most similar to their striped bass counterparts. The $\beta$ GtH-I subunits of blue gourami and striped bass shared $73 \%$ of their residues, and the $\beta$ GtH-II subunits $84 \%$.
\end{abstract}

The cloning of the cDNAs of $\beta$ GtH-I and $\beta$ GtH-II has enabled us to measure the expression of their respective mRNAs in the pituitaries of female blue gourami at different stages of the reproductive cycle. The highest levels of $\beta$ GtH-I and $\beta$ GtH-II mRNA were found in specimens classified as high vitellogenic and in females that were at the final stages of oocyte maturation.

Fournal of Molecular Endocrinology (1999) 23, 177-187

\section{INTRODUCTION}

Oogenesis in teleosts, as in other vertebrates, involves a complex interaction along the brainpituitary-gonad axis. It is generally accepted that gonadotropin-releasing hormone $(\mathrm{GnRH})$ controls the release of gonadotropin $(\mathrm{GtH})$ from the pituitary gland, which, in turn, controls ovarian development (Sherwood et al. 1989, Swanson 1991). Oogenesis is induced by increasing levels of $\mathrm{GtH}$, via the mediation of ovarian steroids, from early growth of primary oocytes to vitellogenesis and through maturation to ovulation.

$\mathrm{GtH}$ is a glycoprotein consisting of two subunits, $\alpha$ and $\beta$, which are non-covalently bound. There are two distinct $\mathrm{GtH}$ in the pituitary gland of teleosts: GtH-I and GtH-II. These proteins share a common $\alpha$ subunit, but differ in their $\beta$ subunits, which confer the immunological and biological specificity to each hormone. In salmonids, GtH-I and GtH-II were found to differ in their pattern of expression at different stages of the reproductive cycle (Nozaki et al. 1990a,b, Swanson 1991). GtH-I is expressed during oocyte vitellogenesis and
GtH-II is expressed at maturation and ovulation (Mal et al. 1989).

Most of the physiological studies of teleost GtHs have been conducted on GtH-II, which controls maturation and ovulation, while the function of GtH-I in fish has not been fully addressed (Elizur et al. 1996). It is believed that GtH-I regulates gametogenesis, since it promotes the production of $17 \alpha$-estradiol (Sekine et al. 1989). GtH-II, on the other hand, is known to be involved in oocyte maturation and ovulation (Nagahama 1994). This hormone is probably responsible for the final maturation of the oocytes (FOM), since it is more active than GtH-I in stimulating the release of the maturation-inducing factor $17 \alpha, 20 \beta$, dihydroxy4-pregnen-3-one produced by post-vitellogenic oocytes (Nagahama 1994).

The $\alpha$ and $\beta$ subunits of teleost GtH-I and/or GtH-II are encoded by separate genes. Trinh et al. (1986) was the first to clone these genes in teleost fish (chinook salmon, Oncorhynchus tshawytscha). Since then, sequencing of $\alpha$ and $\beta$ subunits of both GtH-I and/or GtH-II has been reported for several fish. $\beta$ subunits of GtH-I and GtH-II have been 
cloned and sequenced in chum salmon, Onchorhynchus keta (Itoh et al. 1988), masu salmon, Onchorhynchus masou (Kato et al. 1993), goldfish, Carassius auratus (Yoshiura et al. 1997), mummichog, Fundulus heteroclitus (Lin et al. 1992), European eel, Anguilla anguilla (Querat et al. 1990), baikal omul, Coregonus auumnalis migratorius (Trofimova \& Belikov 1994), and gilthead seabream, Sparus aurata (Elizur et al. 1996). The $\alpha$ and $\beta$ subunits of GtH-I and/or GtH-II have been cloned and sequenced in common carp, Cyprinus carpio (Chang et al. 1993), chum salmon (Sekine et al. 1989), and Japanese eel, Anguilla japonica (Nagae et al. 1996). The $\alpha 1$ and $\alpha 2$ subunits of GtH have been cloned and sequenced in goldfish (Kobayashi et al. 1977) and the channel catfish, Ictalurus punctatus (Liu et al. 1997).

The synthesis and secretion of gonadotropins are regulated by positive and negative factors that act at the levels of brain, pituitary and gonads. Most studies that have described the changes in the level of gonadotropins during the reproductive cycle in teleosts relate to the secretion of gonadotropin, but not to their synthesis. The use of a molecular biological approach has made it possible to examine changes in the levels of the mRNA of the gonadotropins during the gonadal cycle. Changes in the expression of GtHs during the gonadal cycle, or under the influence of different hormones, have been studied in recent years in teleosts (Querat et al. 1991, Weil et al. 1995, Elizur et al. 1996, Nagae et al. 1996, Liu et al. 1997).

The blue gourami (Trichogaster trichopterus) belongs to the family Anabantidae, which contains 16 genera and about 50 species, distributed throughout most of southern Asia, India and Central Africa. This family belongs to the suborder Labyrinthici, which is characterized by the presence of an air-filled breathing cavity (the labyrinth), located above the gills under the operculum. The blue gourami is multi-spawning and maledependent, with an asynchronic ovary development (Degani 1993a,b). Its hormone profile during oogenesis has been studied in detail in our laboratory (Degani \& Boker 1992, Degani 1993a, Degani et al. 1994, 1997). Since each stage of its gonadal development can be controlled and examined separately in the laboratory, the blue gourami provides a useful model to study the role of GtH-I and GtH-II in the hormonal control of oogenesis and the expression of their genes during the gonadal cycle. The aim of the present study was to clone and sequence the cDNAs of the blue gourami $\beta \mathrm{GtH}-\mathrm{I}$ and $\beta$ GtH-II and to quantify the mRNA of these hormones, in order to understand the dynamics of the synthesis of GtH-I and GtH-II in the female blue gourami during the gonadal cycle in fish. The initiation of mRNA synthesis is the first step in the regulation of gene expression and the quantification of mRNA is now commonly used to measure levels of gene expression (Swanson 1991, Dickey \& Swanson 1995, Weil et al. 1995).

\section{MATERIALS AND METHODS}

\section{Fish}

Female blue gouramis (T. trichopterus), maintained and bred at MIGAL Laboratories in northern Israel, were used in this study. The fish were grown in containers measuring $2 \times 2 \times 0.5 \mathrm{~m}$, at a temperature of $27^{\circ} \mathrm{C}$, and under a light regime of $12 \mathrm{~h}$ light:12 h darkness. The fish were fed an artificial diet ( $45 \%$ protein, $7 \%$ fat) supplemented by live food (Artemia salina). The pituitaries were collected from 3 -month-old females $(3 \cdot 5 \pm 0.6 \mathrm{~g})$, at various stages of gonadal development (Degani 1994).

\section{cDNA cloning}

The cloning of the cDNAs of $\beta$ GtH-I and $\beta$ GtH-II was carried out according to the rapid amplification of cDNA ends (RACE)-PCR protocol for the amplification of cDNA ends (Frohman 1990).

RNA extraction and cDNA synthesis Total RNA was extracted from 20 freshly excised pituitaries by means of the Rneasy total RNA kit (QIAGEN, Hilden, Germany). Usually, $40 \mathrm{ng} / \mu$ l total RNA was obtained from each pituitary. The cDNA pools for both the $3^{\prime}$ and $5^{\prime}$ amplifications were synthesized as described by Frohman (1990), using an AMV reverse transcriptase (Promega, Madison, WI, USA). The primer for the synthesis of the $3^{\prime} \mathrm{cDNA}$ end consisted of an oligo dT (17 bases), linked to a unique 17 mer adapter (Table 1: $\mathrm{dT}_{-17}$ adapter). The 5' cDNA end synthesis was performed with specific primers, prepared in each case according to the sequence information previously obtained, by sequencing the $3^{\prime}$ end of the cDNAs (Table 1: primers $\mathrm{P} 2$ and $\mathrm{P} 7)$. The $5^{\prime} \mathrm{cDNA}$ pool was tailed with a poly $A$ stretch, to allow the use of the $\mathrm{dT}_{-17}$ adapter and the adapter primers in both the cDNA synthesis and the 5' RACE-PCR which followed.

Amplification of the $3^{\prime}$ and $5^{\prime}$ ends The PCR primers which were used in the amplification step are listed in Table 1. The degenerate primers were designed according to conserved amino acid sequences which 

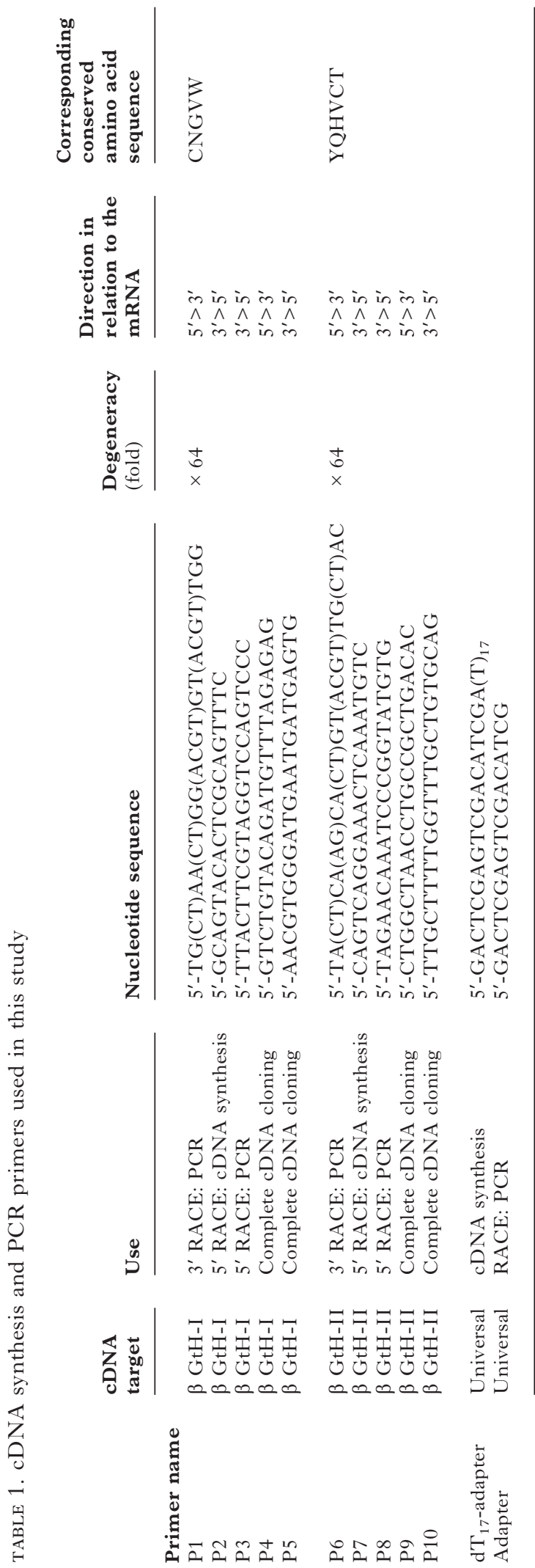

Fournal of Molecular Endocrinology (1999) 23, 177-187

Downloaded from Bioscientifica.com at 04/26/2023 10:37:37AM 
were found in $\beta$ GtH-I and $\beta$ GtH-II. The PCR amplifications were carried out in $100 \mu \mathrm{l}$ reactions, using 2.5 units Taq polymerase (Promega), a suitable reaction buffer (Promega), 1.5 $\mathrm{mM} \mathrm{MgC1}$, $0 \cdot 2 \mathrm{mM}$ of each nucleotide, $25 \mathrm{pmol}$ of each primer, $5 \mu \mathrm{l} \mathrm{cDNA}$ and $20 \mu \mathrm{l}$ mineral oil. Cycling parameters were $3 \mathrm{~min}$ denaturation at $94{ }^{\circ} \mathrm{C}$, followed by 35 cycles, comprising of $1 \mathrm{~min}$ denaturation at $94{ }^{\circ} \mathrm{C}, 1 \mathrm{~min}$ annealing at $54{ }^{\circ} \mathrm{C}$ and $1 \mathrm{~min}$ extension at $72{ }^{\circ} \mathrm{C}$.

The $3^{\prime}$ end of each cDNA was amplified with a degenerate primer, complementary to an internal region (Table 1: primers $\mathrm{P} 1$ and $\mathrm{P} 6$ ), and an adapter primer, which corresponded to the terminal adapter sequence of the cDNA. The $5^{\prime}$ end of each cDNA was amplified with the adapter primer and a second cDNA-specific primer (P2 and P7), situated upstream from the primer which was used in the cDNA synthesis step.

Cloning and sequencing of PCR products The resulting amplified DNA was cloned into a pGEMT vector (Promega) and sequenced as double-stranded DNA. The sequencing was carried out by the Unit for Biological Services, Weizmann Institute. Three separate clones from the same pool were sequenced for each cDNA. All three independent clones of each cDNA end were obtained from the same cDNA pool.

Once the complete sequence information of the two cDNAs was obtained, we designed new pairs of PCR primers, each of them flanking the entire length of its corresponding cDNA (Table 1: primers $\mathrm{P} 4, \mathrm{P} 5, \mathrm{P} 9, \mathrm{P} 10)$. These PCR primers were used to reclone the complete cDNA of $\beta$ GtH-I and $\beta$ GtH-II, using a DNA polymerase with a proofreading capability and an error rate of $8.5 \times 10^{-6}$ (Expand; Boehringer, Mannheim, Germany). The resulting PCR products were subjected to direct sequencing of both strands. The use of high fidelity polymerase and the direct sequencing of PCR products minimized the risk of introducing amplification errors into the sequence data. Comparison of the cDNA sequences from the two cloning steps revealed no differences. Each nucleotide of the three cDNAs was sequenced at least four times, twice on each strand.

\section{Sequence assembly and analysis}

The sequences of each cDNA were assembled with the aid of the GAP4 software package (Bonfield et al. 1995). Sequence analysis was carried out by using various softwares from the GCG package (Genetics Computer Group 1996). Multiple sequence alignments were performed with the aid of PILEUP and converted into distance matrices by DISTANCES software, using the correction method for superimposed substitutions developed by Kimura (1983). Places in which the alignments contained many gaps were eliminated from the distance matrix. The resulting distance matrices were then used to create dendrograms by means of GROW'TREE software, using the unweighted pair group method of arithmetic averages (UPGMA) for cluster analysis (Swofford et al. 1996).

\section{Measurement of $\beta$ GtH-I and $\beta$ GtH-II mRNA levels by RT-PCR}

We have measured the relative levels of both $\beta$ GtH-I and $\beta$ GtH-II mRNAs by reverse transcriptase (RT)-PCR, using the $18 \mathrm{~S}$ rRNA as an internal standard. The RT-PCR method was employed because the very small size of the blue gourami pituitary gland precluded the use of Northern blotting which requires relatively large amounts of RNA (Kawasaki 1990). The 18S rRNA was used as an internal standard of the measurements, since it is an abundant RNA and its expression is considered stable (Ambion Technical Bulletins 1998, Amoureux et al. 1997). It has been observed that the levels of $18 \mathrm{~S}$ rRNA are more uniform than those of other commonly used internal standards, such as $\beta$ actin (Ambion Technical Bulletins). We have determined the uniformity of $18 \mathrm{~S}$ rRNA expression throughout the reproductive cycle, by amplifying its cDNA, using cDNA pools prepared from females at different stages of ovary development. The amount of the resulting PCR products, normalized to $1 \mu \mathrm{g}$ total RNA, is shown in Fig. 1.

RT-PCR was conducted as described above for $3^{\prime}$ RACE-PCR, except that a mixture of random decamers (Biotechnological Services, Weizmann Institute, Rehovot, Israel) was added to the RT reaction for the synthesis of the cDNA of the $18 \mathrm{~S}$ rRNA. A separate cDNA pool was prepared from the pituitary of each sampled fish. In addition, small pieces of the ovary of each female were fixed in Bouin's fixative $(5 \%$ glacial acetic acid, 25\% formaldehyde, $75 \%$ saturated solution of picric acid) and processed for light microscopy, in order to determine the stage of ovary development. At least five female blue gouramis from each of the following stages of the reproductive cycle were used in this study: previtellogenesis (immature females), low and high vitellogenesis (mature non-reproductive females) and FOM (mature reproductive females). The procedure of Jackson et al. (1994) was used to induce mature females to reach FOM. 


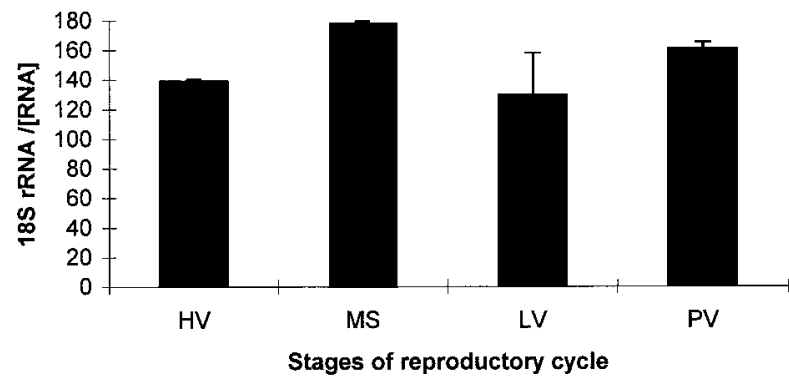

FIGURE 1. Amplification of $18 \mathrm{~S}$ cDNA prepared from pituitaries of female blue gourami at different stages of the reproductive cycle. The different stages are: previtellogenic (PV), low vitellogenesis ( $\mathrm{LV})$, high vitellogenesis (HV) and maturation (MS). The amount of PCR products was normalized per concentration of total RNA $(\mu \mathrm{g} / \mathrm{ml})$, and is expressed in arbitrary units of intensity as defined by the densitometry software (PCBAS-2). Each histogram represents the average of three independent measurements (means \pm S.E.).

Amplification of the cDNA of $\beta$ GtH-I, $\beta$ GtH-II and 18S rRNA Each amplification of either $\beta$ GtH-I or $\beta$ GtH-II cDNA was coupled to an amplification of the internal standard $18 \mathrm{~S}$ rRNA. In each case, the $18 \mathrm{~S}$ rRNA cDNA and the hormone's cDNA were amplified in separate tubes, since many attempts to use multiplex PCR resulted in a considerable interference between the two reactions. Amplification of the $18 \mathrm{~S}$ rRNA cDNA in the same tube with either $\beta$ GtH-I or $\beta$ GtH-II cDNA caused a reduction in one or both PCR products. Such interference problems are not uncommon in multiplex PCR, as reported by Bercovich et al. (1997). We have carefully calibrated the concentration of each primer pair and the number of cycles for amplifications which were linearly dependent on the initial concentration of the target cDNA.

$\beta$ GtH-I and $\beta$ GtH-II cDNAs were amplified with gene specific primers (see Table 1) at a concentration of $6 \cdot 25 \mathrm{pmol} /$ reaction. The $18 \mathrm{~S}$ rRNA cDNA was amplified with specific primers, at a concentration of $5 \mathrm{pmol} /$ reaction, which were obtained from Ambion as part of its Quantum RNA kit. The reagents, except for the cDNA and the primers, were prepared as a batch for each set of reactions, to minimize variations. The cycling parameters were the same as those described for the RACE-PCR, but in a smaller volume $(50 \mu \mathrm{l})$ and with only 30 cycles. The number of cycles was determined by using an increasing number of PCR cycles to amplify serial dilutions of the cDNA pool and then plotting the amount of PCR products as a function of the cDNA pool's dilution. Only 30 cycles produced enough PCR products for the semi-quantitative analysis, while maintaining linear

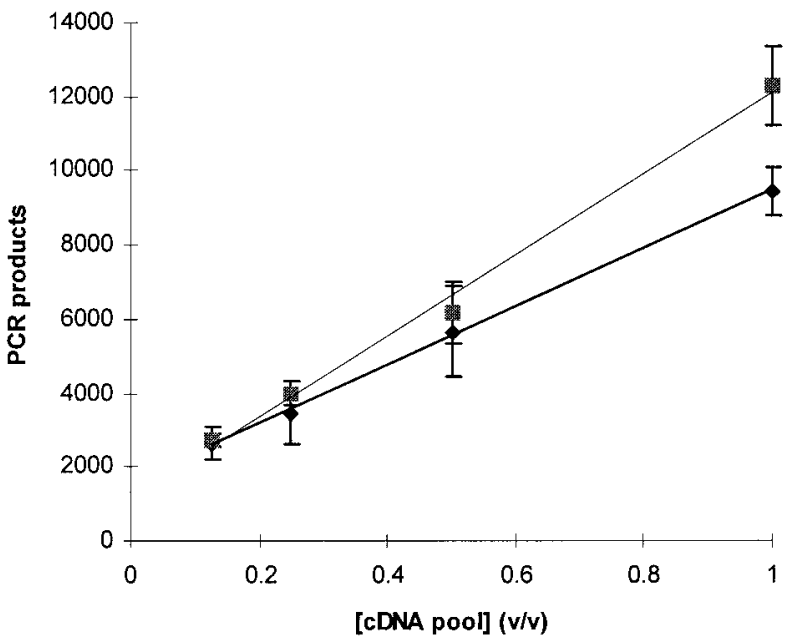

FIGURE 2. The linearity of the amplification of GtH-I and GtH-II cDNAs after 30 cycles. The cDNA pool for the amplification of $\beta \mathrm{GtH}-\mathrm{I}$ (solid diamonds) was obtained from a female at high vitellogenesis. The cDNA pool for the amplification of $\beta$ GtH-II (solid squares) was obtained from a female at the final maturation stage. The amount of PCR products is expressed in arbitrary units of intensity as defined by the densitometry software (PCBAS-2). The coefficients of linearity are: 0.9989 for GtH-I and 0.9946 for GtH-II. Each point is an average of five different reactions.

dependence on the concentration of the cDNA. This linear dependence was kept after 30 cycles even when amplifying cDNA obtained from females in high vitellogenesis or at maturation (Fig. 2).

Quantification of PCR products The PCR products (1/2 of the PCR reaction) were electrophoresed on $2 \%$ agarose gel at $120 \mathrm{~mA}$ for $45 \mathrm{~min}$. The DNA was then stained by ethidium bromide $(0.03 \mathrm{mg}$ in $100 \mu \mathrm{l}$ distillate water), and imaged with the Eagle Eye II Image analysis system (Stratagene, La Jolla, CA, USA). The gels were imaged at three different exposure times to prevent a possible saturation of the images. The resulting images were analyzed with the aid of the PCBAS-2 densitometry software (Raytest, Straubenhardt, Germany). The significance of the differences in the amount of PCR products was analyzed by Student's $t$-test (Parker 1986).

\section{RESULTS}

\section{cDNA cloning and sequence analysis}

The complete cDNAs of the $\beta$ subunits of GtH-I and GtH-II were cloned by RACE-PCR. The 5' 
A.

1 GTCTGTACAGATGTTTAGAGAGTAACAGGCAAAACCTGCAGCAGAGGTTCAACGAGACAA

61 CAGAGATTTACAGGCGTCTGTGCTGCACCCAAAGGATGCAGCTGGTTGTCATGGCAGCAG MetGlnLeuValValMetAlaAlaV

121 TGTTGGCAGTGGCGGGGGTGGGACAGGGTTGCCGCTTCGGCTGTCATCTAACCAACATCA alLeuAlaValAlaGlyValGlyGlnGlyCysArgPheGlyCysHisLeuThrAsnIleS

181 GCTTCCCCGTAGACAGCTGTGGCATCACCGAGTTCATCTACACCACCATATGCGCAGGAC erPheProValAspSerCysGlyIleThrGluPheIleTyrThrThrIleCysAlaGlyH

241 ATTGCTACCACGAGGATCCAGTCTACATCGGCCACGATGACTGGGCTGAACAGAAAATCT isCysTyrHisGluAspProValTyrIleGlyHisAspAspTrpAlaGluGlnLys IleC

301 GTAACGGGGACTGGACCTACGAAGTAAAACACCTACAAGGATGTCCGGTGGCTGTCACGT ysAsnGlyAspTrpThrTyrGluValLysHisLeuGlnGlyCys ProValAlaValThrT

361 ACCCTGTTGCCAGAAACTGCGAGTGTACTGCTTGTAATGCAGGAAACACATACTGTGGTC yrProValAlaArgAsnCysGluCysThrAlaCysAsnAlaGlyAsnThrTyrCysGlyH

421 ACTTTCATGGATACATACCCAGCTGTCTGTGATTTCAAAGGCACTCATCATTCATCCCAC is PheHisGlyTyrIleProSerCysLeu

481 GTTTACTTTGCATCTTTCTCTGATGGTACTAAAATAAACAGATATGTCTTAAAAAAAAAA

541 AAAAAAAAAAAAAAAAAAAAAAAAAAA 570

B.

1 CTGGCTAACCTGCCGCTGACACTAAAGAGGATGATGACTGTAGAAATAAGCAAAGTGTTT MetThrValgluIleserLysvalPhe

61 GTCCTAATGATGTTAAACCTCTTTCTGGGAGCTTCATCTTCCATTTGGTCTGTGGCTCCA ValLeuMe TMetLeuAsnLeuPheLeuGlyAlaSerSerSerIleTrpserValAlaPro

121 GCAGCAGCCTTCCAGCTGCCACCGTGTCAGCTCATCAACCAGACTGTCTCTCTGGAGAAG AlaAlaAlaPheGlnLeuProProCysGlnLeuIleAsnGlnThrValserLeuGluLys

181 GAAGGCTGCCCCAGGTGTCACGCAGTGGAAACGACAATCTGCAGTGGCCACTGCCTCACC GluGlyCys ProArgCysHisAlaValGluThrThrIleCys SerGlyHisCysLeuThr

241 AAGGACCCAATCATCAAGATACCGTTCAGCAATGTGTACCAGCACGTGTGCACATACCGG LysAspProIleIleLysIleProPheSerAsnValTyrGlnHisValCysThrTyrArg

301 GATTTGTTCTATAAGACATTTGAGTTTCCTGACTGTCCTCCTGGTGTGGACCCAGTCGTC AspLeuPheTyrLys ThrPheGluPheProAspCysProProGlyValAspProValVal

361 ACCTACCCTGTGGCTCTGAGCTGCCACTGCAGCCGTTGTGTGATGGACACATCCGATTGC ThrTyrProvalAlaLeuSerCysHisCysSerArgCysValMetAspThrSerAspCys

421 ACCTTCGAGAGTCTTCAGCCAGACTTCTGCATGAATGACATACCTTTCTACTACTAGTCT ThrPheGluSerLeuglnProAspPheCysMetAsnAspIleProPheTyrTyr

541 AAAAAAAAAAAA 552

FIGURE 3. The nucleotide sequences of blue gourami $\beta$ GtH-I (A) and $\beta$ GtH-II (B). The amino acid sequence of each hormone appears in its three-letter code. The GenBank accession number of these sequences are AF157630 and AF157631 respectively. 


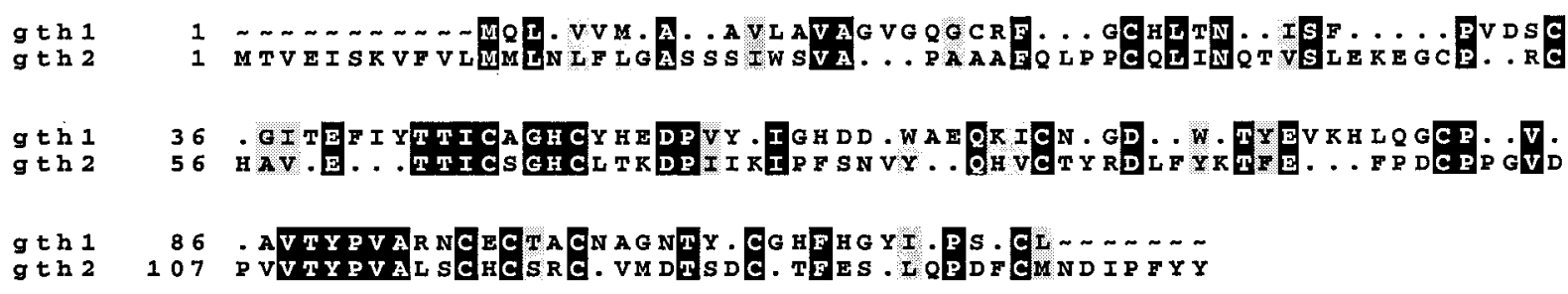

FIGURE 4. A comparison of the amino acid sequences of $\beta$ GtH-I (gth1) and $\beta$ GtH-II (gth2). Identical amino acids are boxed in black whereas residues with similar physicochemical properties are boxed in gray.

and $3^{\prime}$ ends of $\beta$ GtH-I and $\beta$ GtH-II cDNA were cloned separately, but with a short overlap, which allowed their proper joining into a single nucleotide sequence that spanned the entire coding region. The cDNA sequences of both $\beta$ subunits, together with their deduced amino acid sequences, are shown in Fig. 3. A comparison of the two predicted polypeptides is shown in Fig. 4. There was only $\sim 30 \%$ similarity between $\beta$ GtH-I and $\beta$ GtH-II showing that they are very distant from each other. Eleven out of twelve cysteines, which are probably involved in the formation of six disulfide bonds required for proper folding and interaction with the $\alpha$ subunit, represent about a third of the identical residues (Beebe et al. 1990).

We have found that blue gourami $\beta$ GtH-I is most similar to its striped bass (Morone saxatilis) counterpart, with the two polypeptides sharing $73 \%$ of their residues. The lowest similarity was found between blue gourami $\beta$ GtH-I and the $\beta$ GtH-I of the goldfish, with only $44 \%$ of their residues identical. A dendrogram, which graphically represents the relationships among the various $\beta$ subunits of GtH-I, is presented in Fig. 5A. Similarly, when the amino acid sequence of the blue gourami $\beta$ GtH-II was compared with $\beta \mathrm{GtH}-\mathrm{II}$ polypeptides from the same group of fish as in the former comparison, the highest similarity was found with striped bass $\beta \mathrm{GtH}-\mathrm{II}, 84 \%$ of their residues being identical. The lowest similarity was found with the baikal omul $\beta$ GtH-II (only $65 \%$ identical residues). The dendrogram which represents the relationships among the $\beta \mathrm{GtH}-\mathrm{II}$ polypeptides is presented in Fig. 5B.

\section{Variations in the levels of $\beta$ GtH-I and $\beta$ GtH-II mRNAs during the reproductive cycle}

The amplification of $\beta$ GtH-I cDNA produced a $306 \mathrm{bp}$ product and that of $\beta$ GtH-II cDNA a $284 \mathrm{bp}$ product. The amplification of the internal standard (the cDNA of $18 \mathrm{~S}$ rRNA) generated a $430 \mathrm{bp}$ long product. The identity of each PCR product was confirmed by DNA sequencing.
Figure 6 shows an agarose gel electrophoresis of the three PCR products, which were taken from reactions with cDNAs from four different maturation stages.

The variations in the expression of the $\beta$ GtH-I and $\beta$ GtH-II genes at the mRNA level are presented in Fig. 7. Amplification of cDNA from previtellogenic fish resulted in almost undetectable levels of $\beta$ GtH-I and $\beta$ GtH-II specific products, which indicate very low levels of their transcripts. The expression of $\beta$ GtH-I and $\beta$ GtH-II rose at the stage of low vitellogenesis, as manifest by the increased amount of PCR products.

There was a significant increase $(P<0 \cdot 05, t$-test $)$ in the levels of $\beta \mathrm{GtH}-\mathrm{I}$ and $\beta \mathrm{GtH}-\mathrm{II}$ expression in high vitellogenesis and final maturation as compared with the levels which were detected during pre- and low vitellogenesis. On the other hand, there was no significant difference in the levels of $\beta$ GtH-I and $\beta$ GtH-II transcripts measured during high vitellogenesis and final maturation $(P>0 \cdot 05$, $t$-test).

\section{DISCUSSION}

The deduced amino acid sequences of $\beta$ GtH-I, $\beta$ GtH-II of $T$. trichopterus were compared with similar polypeptides from several other teleosts by multiple sequence alignments and cluster analysis. This analysis revealed that both $\beta$ GtH-I and $\beta$ GtH-II of the blue gourami were most similar to their counterparts from the striped bass (Hassin et al. 1995) (Fig. 5). Both of these species belong to the order Perciformes, the largest order of teleosts, with 251 families, and therefore this sequence similarity agrees well with known systematics. It is interesting to note that, in agreement with previous findings (Elizur et al. 1996), our comparison clearly shows that the amino acid sequences of $\beta$ GtH-I have changed more rapidly and show a lower degree of similarity than the corresponding amino acid sequences of $\beta$ GtH-II (Fig. 5). The rapid divergence of $\beta \mathrm{GtH}-\mathrm{I}$, compared with $\beta \mathrm{GtH}-\mathrm{II}$, 

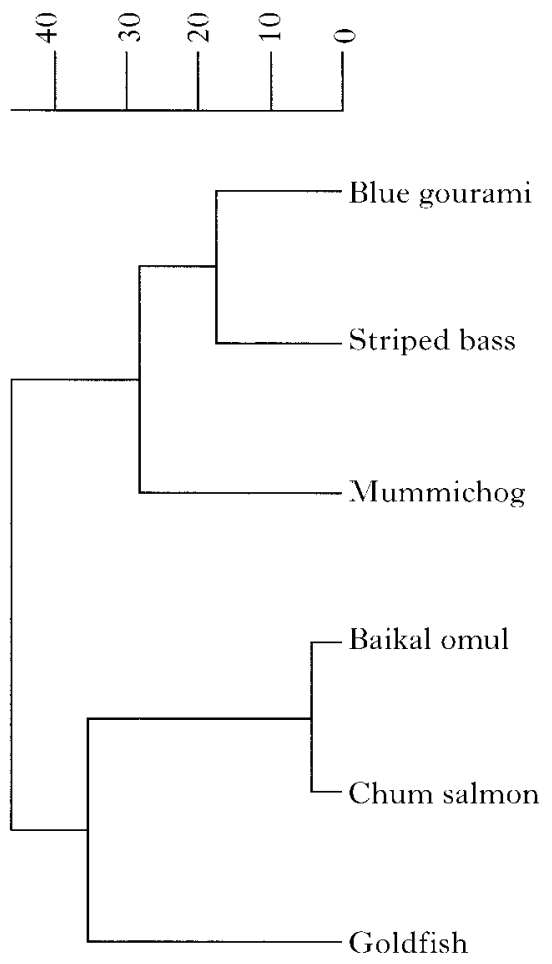
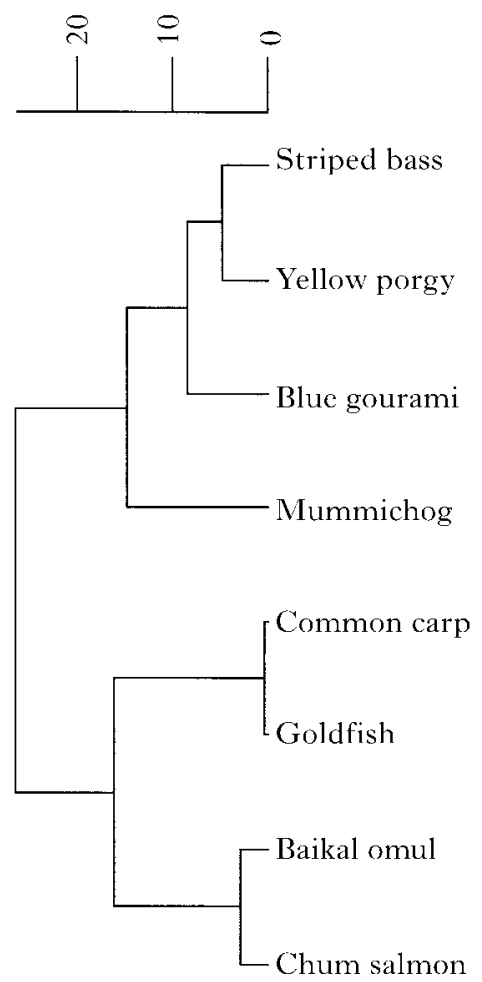

FIGURE 5. Dendrograms which graphically show the relations among various fish $\beta$ GtH-I (A) or $\beta$ GtH-II (B). The dendrograms were created with the method of UPGMA from similarity matrices which were produced from the corresponding sequence alignments. The scale bar is a measure of the estimated number of amino acid substitutions per 100 residues which are found when the sequences are compared in a pairwise fashion.

has already been described in other teleost species (Kato et al. 1993).

It is reasonable to assume that an inference of phylogenetic relations based on only one hormonecoding cDNA would have questionable reliability. However, analyses of two different polypeptide hormones from the blue gourami are presented

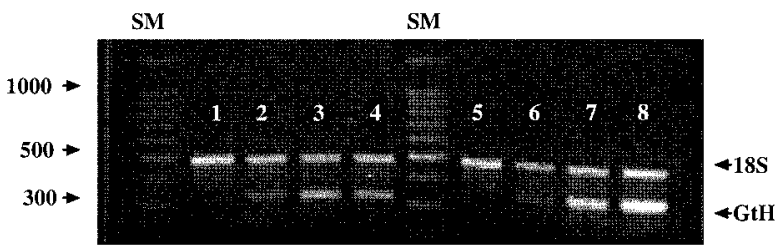

FIGURE 6. Gel electrophoresis of 18S cDNA together with either GtH-I (lanes 1-4) or GtH-II (lanes 5-8) PCR products. Each lane shows amplification of cDNAs prepared from the pituitary of a single female. Young females (lanes 1 and 5), previtellogenic females (lanes 2 and 5), high vitellogenic females (lanes 3 and 7), and females at FOM (lanes 4 and 8$)$. ( $\mathrm{SM}=$ size marker). here, and both are consistent with its classification. The results of the cluster analysis, which positioned the blue gourami close to other members of the order Perciformes, can therefore be regarded as reliable.

In the present study, the temporal differences in the biosynthesis of $\beta \mathrm{GtH}-\mathrm{I}$ and $\beta \mathrm{GtH}-\mathrm{II}$ during gonadal development were determined by studying the changes in their respective mRNAs. GtH-I transcripts were first detected during low vitellogenesis and an accentuated increase occurred during high vitellogenesis and maturation. The participation of GtH-I in vitellogenesis of the teleost has been reported previously (Tyler et al. 1991, 1997). The presence of GtH-I transcripts in the pituitary glands of low vitellogenic females was expected since the deposition of vitellogenin had already started in the most developed oocytes (Degani 1993a). The process of vitellogenesis continues until $30 \%$ to $40 \%$ of the oocytes are at the postvitellogenic stage. An increase in the level of GtH-I transcripts in previtellogenic (Weil et al. 1995) and 
A

GtH -1

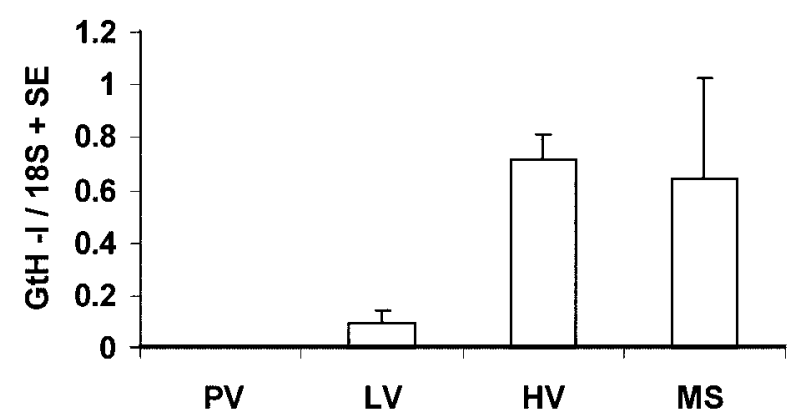

B

GtH - II

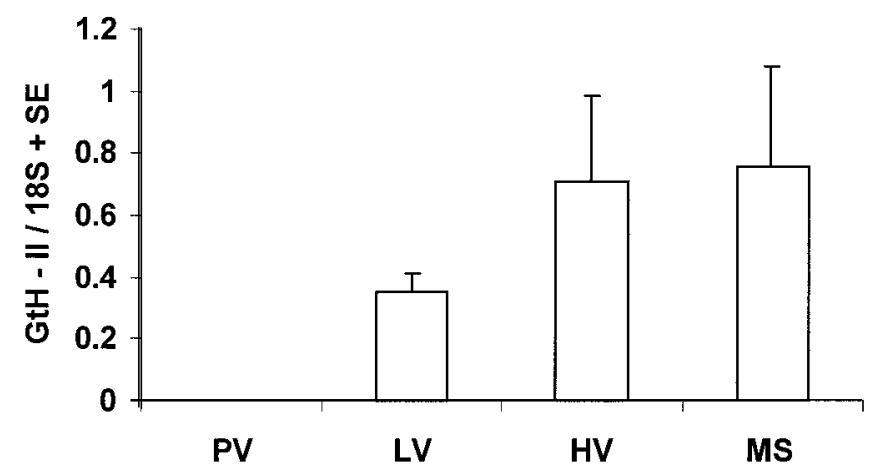

FIGURE 7. Variations in (A) $\beta$ GTH-I and (B) $\beta$ GtH-II transcript levels during the gonadal cycle: previtellogenic (PV), low vitellogenesis (LV), high vitellogenesis (HV), and maturation (MS). Each histogram represents the average of five independent measurements (means \pm s.E.).

vitellogenic teleosts (Naito et al. 1991) has been described previously.

The level of mRNA of $\beta \mathrm{GtH}-\mathrm{I}$ also remains high in reproductive females during the final stage of oocyte maturation. The blue gourami is a multispawner with an asynchronic type of ovary development. The same female can spawn four to five times consecutively with 2- to 3-day pauses between the spawnings (unpublished results, K Jackson \& G Degani). Therefore, vitellogenic oocytes should be found in the ovary of maturating and post-spawned blue gourami females.

A similar pattern of gene expression has been found for GtH-II. The levels of its $\beta$ subunit transcript were undetectable in immature females, rose in low vitellogenic fish and showed a sharp increase during high vitellogenesis. The high level of $\beta \mathrm{GtH}-\mathrm{II}$ transcript remained high at the stage of FOM. An increase in the level of $\beta$ GtH-II mRNA around maturation and spawning has already been 
described (Naito et al. 1991, Weil et al. 1995, Nagae et al. 1996). A similar pattern was observed for GtH-II hormone expression in the blue gourami. The beginning of GtH-II expression is low in vitellogenic fish and it is present in high levels in the pituitaries of high vitellogenic females. However, the hormone is released to the blood only during FOM (Degani et al. 1997).

It has been suggested that estrogens and androgens stimulate GtH-II synthesis in the pituitary (Querat et al. 1991, Huggard et al. 1996, Nagae et al. 1996). Dickey \& Swanson (1995) found that in immature coho salmon injected with estradiol there was an increase in the steadystate mRNA levels of $\beta$ GtH-II but not $\beta$ GtH-I. The presence of a steroid response element in the promoter for the $\beta$ GtH-II subunit gene has already been described in salmonids (Xiong et al. 1994). We have found an increase in the level of $\beta$ GtH-II mRNA in the pituitaries of low vitellogenic females, which may be the result of the rise in the levels of estradiol in low vitellogenic females (Degani 1990). The steady high levels of $\beta$ GtH-II mRNA in high vitellogenesis and during FOM may be a consequence of the synthesis and release of other regulatory factors, such as $\mathrm{GnRH}$, since at this time there is a decrease in the level of estradiol (Degani 1990). GnRH affects GtH biosynthesis and was shown to cause an increase in the levels of $\alpha$ and $\beta$ GtH-II mRNAs (Khakoo et al. 1994).

In the blue gourami, both GtH-I and GtH-II RNA levels increase during the advancement of the gonadal cycle. This pattern is similar to that found in goldfish (Yoshiura et al. 1997) and gilthead seabream (Sparus aurata) (Meiri et al. 1995, Elizur et al. 1996). Both are multi-spawners with group-synchronic or asynchronic type of ovary development. This pattern differs from that found in salmonids, where GtH-I is expressed during vitellogenesis and GtH-II during late vitellogenesis and FOM, as was found in rainbow trout (Naito et al. 1991, Weil et al. 1995), an annual spawner with a synchronous type of ovary. The difference in the pattern of GtH-I and GtH-II gene expression is probably related to the different types of gonadal cycles: multi-spawners versus annual spawners.

\section{ACKNOWLEDGEMENT}

We would like to thank Dr Abigail Elizur for her assistance.

\section{REFERENCES}

Ambion Technical Bulletins 1998 Use of Internal and External Standards or Reference RNAs for Accurate Quantitation of RNA Levels.
Amoureux MC, Van Gool D, Herrero MT, Dom R, Colpaert F \& Pauwels P 1997 Regulation of metallothionein-III (GIF) mRNA in the brain of patients with Alzheimer disease is not impaired. Molecular and Chemical Neuropathology 32 101-121.

Beebe JS, Mountjoy K, Krzesicki RF, Perini F \& Ruddon RW 1990 Role of disulfide bond formation in the folding of human chorionic gonadotropin beta subunit into an alpha beta dimer assembly-competent form. Fournal of Biological Chemistry 265 312-317.

Bercovich D, Regev Z, Ratz T \& Plotsky Y 1997 The effect of quantitative ratio between primer pairs on PCR products in multi-target amplifications. In Modern Applications of DNA Amplification Techniques: Problems and New Tools, pp 83-89. Eds D Lassner, B Pustowoit \& A Rolfs. New York and London: Plenum Press.

Bonfield JK, Smith K \& Staden R 1995 A new DNA sequence assembly program. Nucleic Acids Research 23 4992-4999.

Chang YS, Huang FL \& Lo TB 1993 Isolation and sequence analysis of carp gonadotropin $\beta$-subunit gene. Molecular Marine Biology and Biotechnology 1 97-105.

Degani G 1990 The effect of human chorionic gonadotropin on steroid changes in Trichogaster trichopterus. Comparative Biochemistry and Physiology 96A 525-528.

Degani G 1993a The effect of sexual behavior on oocyte development and steroid changes in Trichogaster trichopterus. Copeia 4 1091-1096.

Degani G 1993b Reproduction control in multi-spawning asynchronic Trichogaster trichopterus (Pallas) as a model for the anabantidae family. Trends in Comparative Biochemistry and Physiology 1269-1275.

Degani G 1994 Effect of gonadotropin and steroids on vitellogenesis during ovarian development in Trichogaster trichopterus. Fournal of Aquaculture in the Tropics 9 $15-23$.

Degani G \& Boker R 1992 Sensitivity to maturation-inducing steroids and gonadotropin in the oocytes of blue gourami Trichogaster trichopterus (Anabantidae, Pallas 1770). General and Comparative Endocrinology 85 430-439.

Degani G, Gal E \& Vaya J 1994 In vitro biosynthesis of steroids in female Trichogaster trichopterus (Pallas 1770). Comparative Biochemistry and Physiology 109B 715-725.

Degani G, Mananos EL, Jackson K, Abraham M \& Zohar Y 1997 Changes in plasma and pituitary GtH-II levels in vitro and in vivo in female blue gourami during the end of vitellogenesis and final oocyte maturation. Fournal of Experimental Zoology 279 377-385.

Dickey JT \& Swanson P 1995 Development of RNAse protection assays for quantification of gonadotropin (GtH-I and GtH-II) subunit transcript levels in coho salmon (Oncorhynchus kisutch). Proceedings of the Fifth International Symposium of Reproductive Physiology in Fish. Abstract no. 28.

Elizur A, Zmora N, Rosenfeld H, Meiri I, Hassin S, Gordin H \& Zohar Y 1996 Gonadotropin GtH-I and GtH-II from the gilthead seabream. Sparus auratus. General and Comparative Endocrinology 102 39-46.

Frohman MA 1990 RACE: rapid amplification of cDNA ends. In PCR Protocols: A Guide to Methods and Applications, pp 28-38. Eds MA Innis, DH Gelfand, JJ Sninsky \& TJ White. San Diego, CA: Academic Press Inc.

Genetics Computer Group (GCG) 1996 Wisconsin Package Version 9.0. Madison, WI: GCG.

Hassin S, Elizur A \& Zohar Y 1995 Molecular cloning and sequence analysis of striped bass (Morone saxatilis) gonadotropin I and II subunits. Fournal of Molecular Endocrinology 15 23-35.

Huggard D, Khakoo Z, Kassam G, Mahmoud SS \& Habibi HR 1996 Effect of testosterone on maturational 
gonadotropinsubunit messenger ribonucleic acid levels in the goldfish pituitary. Biology of Reproduction 54 1184-1191.

Itoh H, Suzuki K \& Kawauchi H 1988 The complete aminoacid sequence of $\beta$ units of two distinct salmon gonadotropins. General and Comparative Endocrinology 71 438-451.

Jackson K, Abraham M \& Degani G 1994 Oocyte maturation triggered by the presence of male in the blue gourami, Trichogaster trichopterus. Fournal of Morphology 220 $1-9$.

Kato Y, Gen K, Maruyama O, Tomizawa K \& Kato T 1993 Molecular cloning of cDNAs encoding two gonadotrophin subunits (GTH-I $\beta$ and -II $\beta$ ) from the masu salmon, Oncorhynchus masou: rapid divergence of the GTH-I $\beta$ gene. Fournal of Molecular Endocrinology 11 275-282.

Kawasaki ES 1990 Amplification of RNA. In PCR Protocols: A Guide to Methods and Applications, pp 21-27. Eds MA Innis, DH Gelfand, JJ Sninsky \& TJ White. San Diego, CA: Academic Press Inc.

Khakoo Z, Bhatia A, Gedamu L \& Habibi H 1994 Functional specificity for salmon gonadotropin-releasing hormone $(\mathrm{GnRH})$ and chicken GnRH-II coupled to the gonadotropin release and subunit messenger ribonucleic acid level in the goldfish pituitary. Endocrinology 134 838-847.

Kimura M 1983 The Neutral Theory of Molecular Evolution. Cambridge: Cambridge University Press.

Kobayashi M, Kato Y, Yoshiura \& Aida K 1977 Molecular cloning of cDNA encoding two types of pituitary gonadotropin $\alpha$ subunit from the goldfish, Carassius auratus. General and Comparative Endocrinology 105 372-378.

Lin YW, Rupnow BA, Price DA, Greenberg RM \& Wallace RA 1992 Fundulus heteroclitus gonadotropins. 3. Cloning and sequencing of gonadotropic hormone $(\mathrm{GtH})$ I and II $\beta$ subunits using the polymerase chain reaction. Molecular and Cellular Endocrinology 85 127-139.

Liu Z, Li P, Argue BJ \& Dunham RA 1997 Gonadotropin a subunit glycoprotein from channel catfish (I. punctatus) and its expression during hormone-induced ovulation. Molecular Marine Biology and Biotechnology 6 217-227.

Mal AO, Swanson P \& Gickhoff WW 1989 Immunocytochemistry of the developing salmon pituitary gland. American Zoologist 29 94a.

Meiri I, Gothilf Y, Knibb WR, Zohar Y \& Elizur A 1995 Preovulatory changes in gonadotropin gene expression and secretion in the gilthead seabream Sparus aurata. Proceedings of the Fifth International Symposium of Reproductive Physiology of Fish. Eds FW Goetz \& P Thomas. Abstract no. 37. Austin, USA: Fish Symposium 95.

Nagae M, Todo T, Gen K, Kato Y, Young G, Adachi S \& Yamauchi KJ 1996 Molecular cloning of the cDNAs encoding pituitary glycoprotein hormone $\alpha$ and gonadotropin-II $\beta$ subunits of the Japanese eel, Anguilla japonica, and increase in their mRNAs during ovarian development induced by injection of chum salmon pituitary homogenate. Molecular Endocrinology 16 171-181.

Nagahama Y 1994 Endocrine regulation of gametogenesis in fish. International Fournal of Developmental Biology 38 217-229.

Naito N, Hyodo S, Okumoto N, Urano A \& Nakai Y 1991 Differential production and regulation of gonadotropins GTH-I and GTH-II in the pituitary gland of the rainbow trout, Oncorhynchus mykiss, during ovarian development. Cell and Tissue Research 266 457-467.

Nozaki M, Naito N, Swanson P, Miyata K, Nakai Y, Oota Y, Suzuki K \& Kawauchi H $1990 a$ Salmonid pituitary gonadotrophs. I. Distinct cellular distributions of two gonadotropins, GTH-I and GTH-II. General and Comparative Endocrinology 77 348-357.

Nozaki M, Naito N, Swanson P, Dickhoff WW, Nakai Y, Suzuki K \& Kawauchi H $1990 b$ Salmonid pituitary gonadotrophs. II. Ontogeny of GtH-I and GtH-II cells in the rainbow trout (Salmo gairdneri irideus). General and Comparative Endocrinology 77 358-367.

Parker RE 1986 Introduction to Statistics for Biology, pp 26-28. London: Edwin Arnold.

Querat B, Moumni M, Jutisz M, Fontaine YA \& Counis R 1990 Molecular cloning and sequence analysis of cDNA for the putative $\beta$ subunit of the type-II gonadotrophin from the European eel. Fournal of Molecular Endocrinology 4 257-264.

Querat B, Hardy A \& Fontaine YAJ 1991 Regulation of the type-II gonadotropin $\alpha$ and $\beta$ subunit mRNAs by estradiol and testosterone in the European eel. Molecular Endocrinology 7 81-96.

Sekine S, Saito A, Itoh H, Kawauchi H \& Itoh S 1989 Molecular cloning and sequence analysis of chum salmon gonadotropin cDNAs. Proceedings of the National Academy of Sciences of the USA 86 8645-8649.

Sherwood NM, Leeuw R \& Goos H 1989 A new member of the gonadotropin-releasing hormones. General and Comparative Endocrinology 75 427-436.

Swanson P 1991 Salmon gonadotropins: reconciling old and new ideas. In Proceedings of the 4th International Symposium on Reproductive Physiology of Fish. Fish Symposium 91, Sheffield UK, pp 30-34. Eds AP Scott, DE Kime \& MS Rolfe.

Swofford DL, Olsen GJ, Waddell PJ \& Hillis DM 1996 Phylogenetic inference, pp 407-514. In Molecular Systematics, edn 2. Eds DM Hillis, C Moritz \& BK Mable. Sunderland, MA, USA: Sinauer Associates.

Trinh KY, Wang NC, Hew CL \& Crim LW 1986 Molecular cloning and sequencing of salmon gonadotropin $\beta$ subunit. European Fournal of Biochemistry 159 619-624.

Trofimova IN \& Belikov SI 1994 Cloning and sequencing the cDNA for the $\beta$ subunit of Baikal omul gonadotropin. Molecular Biology 28 1052-1056.

Tyler CR, Sumpter JP, Kawauchi H \& Swanson P 1991 Involvement of gonadotropin in the uptake of vitellogenin into the oocytes of the rainbow trout, Oncorhynchus mykiss. General and Comparative Endocrinology 84 291-299.

Tyler CR, Pottinger TG, Coward K, Beresford N \& Maddix S 1997 Salmonid follicle-stimulating hormone (GTH-I) mediates vitellogenic development of oocytes in the rainbow trout, Oncorhynchus mykiss. Biology of Reproduction $\mathbf{5 7}$ 1238-1244.

Weil C, Bougoussa-Houadec M, Gallais C, Itoh S, Sekine S \& Voltaire Y 1995 Preliminary evidence suggesting variations of GTH-I and GTH-II mRNA levels at different stages of gonadal development in rainbow trout, Oncorhynchus mykiss. General and Comparative Endocrinology 100 327-333.

Xiong F, Liu D, Le Drean Y, Elsholtz HP \& Hew CL 1994 Differential recruitment of steroid hormone response elements may dictate the expression of the pituitary gonadotropin II $\beta$ subunit gene during salmon maturation. Molecular Endocrinology 8 782-793.

Yoshiura Y, Kobayashi M, Kato Y \& Aida K 1997 Molecular cloning of the cDNAs encoding two gonadotropin $\beta$ subunits (GTH-I $\beta$ and GTH-II $\beta$ ) from the goldfish, Carassius auratus. General and Comparative Endocrinology 105 379-389.

REVISED MANUSCRIPT RECEIVED 26 April 1999 